2. Долганов А.В. Шламы медно-колчеданных рудников: проблемы и пути решения // Горный информационно-аналитический бюллетень. 2013. № 4. С. 10-14.

3. Овчинников Н.П., Викулов М.А., Бочкарев Ю.С., Довиденко Г.П. // Экспериментальные исследования эксплуатационных свойств насосной установки с изношенным рабочим колесом. Горный журнал. 2016. № 9. С. 85-88.

4. Островский В.Г., Пещеренко С.Н. Расчет скорости гидроабразивного износа межступенчатых уплотнений нефтяного насоса // Вестник Пермского национальноисследовательского политехнического института. Геология. Нефтегазовое дело. 2012. № 5. C. 70-75.

\title{
Опытно-методические комплексные георадиолокационные исследования криолитозоны в условиях развития криопэгов
}

\author{
Омельяненко П.А., \\ Институт мерзлотоведения им. П.И. Мельникова СО РАН, \\ 2. Якутск, \\ E-mail: omepavel@yandex.ru \\ Куляндин Г.А., \\ Институт горного дела Севера им. Н.В. Черского СО РАН, \\ 2. Якутск, \\ E-mail: gansik.ku@mail.ru
}

Особенности природно-климатических условий криолитозоны, изменчивость криогенного состояния верхней части литосферы, многообразие задач инженерногеологического профиля, и специфика геоэкологических исследований требуют разработки новых методических подходов и реализации современных геофизических технологий. Эффективность этого направления работ непосредственно связана с совершенствованием геофизических методов, что в итоге стимулирует технологическое развитие отрасли в инженерной геологии.

Для повышения эффективности георадиолокационных исследований криолитозоны разработана методика профилирований, зондирований и методика полевого изучения свойств грунтов с целью совершенствования интерпретационных моделей.

В соответствии с задачами апробации комплексной методики выбран оптимальный объект для натурного моделирования - полигон «Криопэг» ИМЗ СО РАН, на котором проверен комплекс электроразведочных работ, включающий методы георадиолокации. На этапе рекогносцировочных работ отработана методика полевых работ, выбраны оптимальные параметры измерений методиками георадиолокации и получены комплексные данные измерений по трем взаимно пересекающимся профилям, вблизи точек опорного бурения.

Измерения проведены методом двухспектральной георадиолокации, методиками профилирований и зондирований с GPS регистрацией точек измерений. В точках опорных наблюдений, для повышения разрешающей способности по глубине и повышения достоверности исследований, проведены георадиолокационные зондирования по разработанной методике угловых сканирований. 
На рисунке 1 приведён фрагмент георадиолокационной съемки высокого разрешения. В точках зондирований Т290 и Т291 подавлены динамические помехи и достоверно выделены границы на глубинах 2м и 4,5 $\pm 0,5$ м. Граница на глубине $\sim 7,5 \mathrm{M}$ энергетически слабо выражена, но интерпретационно определяется в точках зондирований. Определен предел глубинности 8м, при этом, разрешение с глубиной не меняется и составляет 0,2м.

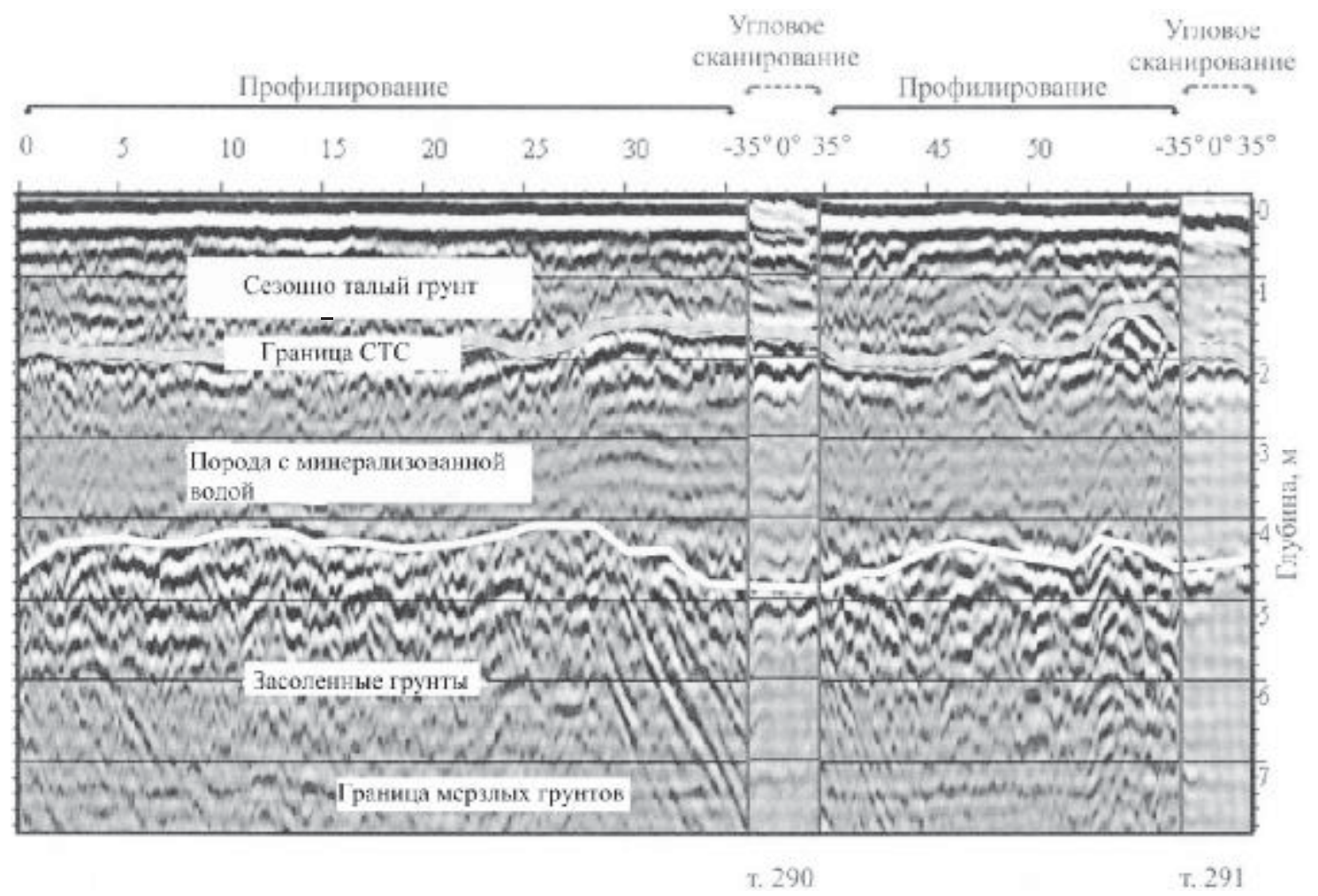

Рис. 1

В результате проведенных исследований установлено, что комплексная методика георадиолокации позволяет изучать геокриологические разрезы включающие криопэги, при этом:

- геокриологический разрез детально описывается с разрешением 0,2м;

- до глубины 5м прослеживаются границы литологических разностей и отображается слой сезонного протаивания.

- с достаточной точностью представляется геокриологический разрез в пределах глубин до 8м.

Использование данных опорного бурения повышает достоверность и качество интерпретаций материалов исследований.

Ограничение по применению: наличие металлических включений (обломки свай, арматуры, обсадка скважин и т.д.) приводит к невосполнимой потере информации.

Применение современных методов георадиолокации, в комплексе инженерногеологических изысканий в области распространения криолитозоны, позволяет получать более полное представление о горных породах не увеличивая объем планируемых буровых работ.

Работа выполнена при поддержке гранта РФФИ 15-45-05050 